\title{
Influence of Welding Energy on Intergranular and Pitting Corrosion Susceptibility of UNS S32205 Duplex Stainless-steel Joints
}

\author{
Henrique Boschetti Pereira ${ }^{a *}$, Tarcisio Henrique Carvalhaes Pimentel ${ }^{a, b}$, Carlos Alberto da Silva ${ }^{a, b}$, \\ Zehbour Panossian ${ }^{a, b}$, Cesar Roberto Farias de Azevedo ${ }^{a}$ (1) \\ ${ }^{a}$ Universidade de São Paulo, Escola Politécnica, Departamento de Engenharia Metalúrgica e de \\ Materiais, São Paulo, SP, Brasil. \\ ${ }^{b}$ Instituto de Pesquisas Tecnológicas do Estado de São Paulo, São Paulo, SP, Brasil.
}

Received: September 22, 2021; Revised: December 21, 2021; Accepted: January 12, 2022

\begin{abstract}
This study analysed the integrity of welded joints of a UNS S32205 duplex stainless steel, using different welding energies: $0.5 \mathrm{~kJ} \cdot \mathrm{mm}^{-1}, 1.0 \mathrm{~kJ} \cdot \mathrm{mm}^{-1}$, and $3.5 \mathrm{~kJ} \cdot \mathrm{mm}^{-1}$. Microstructural characterisation, tensile testing, intergranular attack susceptibility testing (ASTM A262 practice A) and pitting/crevice corrosion resistance tests (critical pitting temperature test, ASTM G48 practice C) were performed in these welded joints. The results showed that the tensile properties of the welded joints did not vary significantly with the welding energy. The microstructure's ferrite content in the molten zone (MZ) was proportional to the welding energy: the ferrite concentration in the $0.5 \mathrm{~kJ} . \mathrm{mm}^{-1}$ weldings was approximately $75 \%$. When the welding energy increased to $3.5 \mathrm{~kJ} \cdot \mathrm{mm}^{-1}$, the amount of ferrite dropped to $54 \%$. The $3.5 \mathrm{~kJ} \mathrm{~mm}^{-1}$ welded joint featured a comparatively higher proportion of coarser austenite grains. The HAZ of the $3.5 \mathrm{~kJ} . \mathrm{mm}^{-1}$ welded joint was comparatively more susceptible to the intergranular attack along the $\alpha / \gamma$ interfaces, while in the base metal and the other two welded joints, the intergranular attack along the $\alpha / \gamma$ interfaces was not prominent. Additionally, the pitting corrosion took place preferentially in the ferrite phase of the HAZ for all welding conditions.
\end{abstract}

Keywords: duplex stainless-steel, UNS S32205, welding energy, intergranular corrosion, pitting corrosion.

\section{Introduction}

Wrought and cast duplex stainless steels are commonly used in the oil extraction industry due to their high mechanical strength and corrosion resistance. Their microstructure is composed of austenite (FCC) and ferrite (BCC $)^{1,2}$, and there are different classes of duplex stainless steels which are classified by their PREN (Pitting Resistance Equivalent Number $)^{3}$ value, see Equation 1, which varies from 24.5 to $48.1^{4}$.

$$
\text { PREN }=\% C r+3.3(\% M o+0.5 \% W)+16(\% N)
$$

The proportion of $\alpha$ and $\gamma$ phases in duplex-stainless steels also depends on the cooling rate from the ferritic field. Therefore, high cooling rates from the ferrite field may hinder the austenite nucleation and growth, as the ferrite decomposition into austenite presents $\mathrm{C}$-curve kinetics in the TTT diagram ${ }^{5,6}$. Furthermore, modern duplex-stainless steels might contain nitrogen which promotes the precipitation of chromium nitride within the ferrite during cooling ${ }^{2,7,8}$. Thermal exposure of duplex stainless steels might encourage the precipitation of Cr-rich intermetallic phases, such as sigma phase $(\sigma)$, chi phase $(\chi)$ or alfa-prime phase $\left(\alpha^{\prime}\right)$. The sigma phase precipitates preferentially at the $\alpha / \gamma$ grain boundaries after long exposure at high temperatures (from $700{ }^{\circ} \mathrm{C}$ to $1000{ }^{\circ} \mathrm{C}$ ), and its growth consumes the ferrite phase $e^{9-11}$ preferentially. The $\alpha$ 'phase features a high chromium

*e-mail: henrique.boschetti.pereira@usp.br concentration and is formed by spinodal decomposition at temperatures between $300{ }^{\circ} \mathrm{C}$ and $550{ }^{\circ} \mathrm{C}^{6}$. Studies using isothermal treatments of duplex stainless steels showed that the precipitation of the Cr-rich sigma phase significantly reduces the corrosion resistance ${ }^{11,12}$. The precipitation of $\mathrm{Cr}$-rich phases creates a Cr-depleted zone in the adjacent areas, locally reducing the corrosion resistance, also known as sensitisation ${ }^{6,13,14}$. The solubilisation of these $\mathrm{Cr}$-rich phases revokes the sensitisation ${ }^{15-17}$. Moreover, in several cases, a more significant proportion of ferrite in the duplex microstructure reduces the corrosion resistance, suggesting that the localised corrosion preferentially nucleates in the weld bead region, which features higher ferrite content, as verified by Gennari et al. ${ }^{18}$. The localised corrosion may later evolve to stress corrosion cracking depending on the environmental and stress conditions, as shown by Pereira and Azevedo ${ }^{19-21}$.

The oil-extraction sites in Brazil are mainly located offshore, a very aggressive environment. Therefore, duplex-stainless steel is widely used and some of these components are manufactured using welding processes, such as GTAW (Gas-Shielded Tungsten Arc Welding) or GMAW (Gas Metal Arc Welding). Both methods promote the heating at the weld bead site, generating a thermal cycle that can cause microstructural changes in the adjacent regions, known as the heat-affected zone (HAZ) $)^{22}$. The N-133 Petrobras 
standard ${ }^{23}$ provides some recommendations for the welding process of duplex stainless steels: the ferrite/austenite ratio in the melted zone (MZ) should be between $35 \%$ and $65 \%$; the welding energy should be between $0.7 \mathrm{~kJ} . \mathrm{mm}^{-1}$, and $1.5 \mathrm{~kJ} . \mathrm{mm}^{-1}$ for joints between $7 \mathrm{~mm}$ and $20 \mathrm{~mm}$ thick; and the maximum $\mathrm{CO}_{2}$ composition in the shielding gas must be a maximum of $2 \%$. Also, this standard recommends the qualification of the welding procedure by practice $A$ of the ASTM G48 ${ }^{24}$ standard. The Petrobras N-133 standard requests that the test for detecting susceptibility to intergranular attack be performed for $24 \mathrm{~h}$ at $20^{\circ} \mathrm{C}$. The ASTM G48 ${ }^{24}$ standard establishes that this corrosion test should be done for $72 \mathrm{~h}$ at either $22^{\circ} \mathrm{C}$ or $50^{\circ} \mathrm{C}$. Additionally, the duplex stainlesssteel joints should not operate at temperatures above $250{ }^{\circ} \mathrm{C}$.

Several studies regarding the corrosion of welded joints have been performed using method A of the ASTM G48 ${ }^{24}$ standard. However, only a few ${ }^{25,26}$ have established a relationship between the microstructure of the duplex stainless steel welded joints and the corrosion properties. Salinas-Bravo and Newman ${ }^{25}$ determined the critical pitting nucleation temperature for $25 \% \mathrm{Cr}$ duplex-stainless steels, which were welded by the GTAW and SMAW (Shielded Metal Arc Welding) methods using different welding energies: $0.8 \mathrm{~kJ} . \mathrm{mm}^{-1}, 1.2 \mathrm{~kJ} . \mathrm{mm}^{-1}$ and $2.1 \mathrm{~kJ} . \mathrm{mm}^{-1}$. The critical pitting-nucleation temperatures obtained by method A of the ASTM G48 standard ${ }^{24}$ (after $24 \mathrm{~h}$ exposure) were $66^{\circ} \mathrm{C}$ for the base metal, $36.5^{\circ} \mathrm{C}$ for $0.8 \mathrm{~kJ}$. $\mathrm{mm}^{-1}, 34.5^{\circ} \mathrm{C}$ for $1.2 \mathrm{~kJ} . \mathrm{mm}^{-1}$ and $24{ }^{\circ} \mathrm{C}$ for $2.1 \mathrm{~kJ} . \mathrm{mm}^{-1}$. According to the authors, this is mainly due to the alloying elements partition variation in HAZ, which also depends on the heat input of the welding process. Nowacki and Rybicki ${ }^{26}$ studied the mass loss of UNS S31803 steel welded by the SAW (Submerged Arc Welding) process, varying the heat input from $3.0 \mathrm{~kJ} . \mathrm{mm}^{-1}$ to $5.0 \mathrm{~kJ} . \mathrm{mm}^{-1}$ at a step of $0.5 \mathrm{~kJ} . \mathrm{mm}^{-1}$. The resulting mass loss obtained by method A of the ASTM G48 standard ${ }^{24}$ (after $24 \mathrm{~h}$ exposure) was inversely proportional to welding energy, ranging from $1.15 \mathrm{mg}$ for $3.0 \mathrm{~kJ} . \mathrm{mm}^{-1}$ to $1.05 \mathrm{mg}$ for $5.0 \mathrm{~kJ} . \mathrm{mm}^{-1}$. Also, the microstructural examination of the welded metal did not find sigma, carbide and other intermetallic phases. Paulraj and $\operatorname{Garg}^{27}$ studied the correlation between the welding parameters of high and low PREN duplex-stainless steels, which were welded by the GTAW process using welding energy from $1.05 \mathrm{~kJ} . \mathrm{mm}^{-1}$ to $1.2 \mathrm{~kJ} . \mathrm{mm}^{-1}$. They concluded that the corrosion rate increased with the welding energy. They explained this result by the secondary austenite precipitation and the formation of intermetallic phases during the thermal cycling of the welds with higher heat inputs. Recent studies ${ }^{19,20,21}$ performed on UNS S32205 duplex stainless steel have shown that the nucleation of SCC (stress corrosion cracking) may occur in corrosion pits ${ }^{28}$. At temperatures between $70{ }^{\circ} \mathrm{C}$ and $110^{\circ} \mathrm{C}$ in a synthetic seawater-dropping-solution environment, the preferential corrosion of the ferrite has been observed ${ }^{19,20}$.

According to worldwide experts of the welding community, the usual welding energy input for UNS S32205 duplex stainless-steel is between $0.4 \mathrm{~kJ}_{\mathrm{mm}} \mathrm{mm}^{-1}$ and $2.5 \mathrm{~kJ} . \mathrm{mm}^{-1}$. The present investigation characterises the microstructure and corrosion properties (pitting and intergranular corrosion resistance according to the ASTM
G48 and ASTM A262 standards) of a UNS S32205 duplex stainless steel produced by the GMAW process using different welding energies. A welding energy of $3.5 \mathrm{~kJ} . \mathrm{mm}^{-1}$, higher than the recommended upper limit ${ }^{23}$, was also investigated. Furthermore, this over-critical welding condition was performed with two consecutive passes to promote the precipitation of Cr-rich precipitates in UNS S32205 plates with a thickness of $12.7 \mathrm{~mm}$. The investigation of the microstructure and corrosion properties of this extreme welding condition compared to normal conditions is the main novelty of this paper. The study of susceptibility to pitting corrosion is essential to improve the reliability of the structural integrity, particularly on the macro and microstructural heterogeneities generated by the welding processes. The main objective of this research is to verify the microstructural evolution of UNS S32205 duplex-stainless steel welding and its influence on the tensile properties and the susceptibility to pitting corrosion by ASTM A262 practice $\mathrm{A}^{29}$ and ASTM G48 practice $\mathrm{A}^{24}$.

\section{Materials and Methods}

The base metal used in this research was a $12.7 \mathrm{~mm}$ thick plate of UNS S32205 duplex stainless steel. The plate was solubilised at $1100{ }^{\circ} \mathrm{C}$ and cooled in water to avoid the grain boundary precipitation of the sigma phase (sensitisation). The chemical composition is described in Table 1, along with the acceptance range according to ASTM A $240^{30}$. The combustion and fusion methods were used to determine the carbon and sulfur content using Leco ${ }^{\circledR}$ analyser CS-300, according to ASTM E1019³1. The X-ray emission spectrometric method was used for the other alloying elements determination using a Panalytical ${ }^{\circledR}$ spectrometer PW2404, according to ASTM E572 ${ }^{32}$.

A V-shaped chamfer $\left(60^{\circ}\right.$ opening, $0.5 \mathrm{~mm}$ nose and no spacing) was machined at the centre of the plate. The welding consumable was ER2209 (see chemical composition in Table 1). Gas-Shielded Metal Arc Welding (60\% Ar, $38 \% \mathrm{He}$ and $2 \% \mathrm{CO}_{2}$ ) with a flow rate between $16 \mathrm{~L} . \mathrm{min}^{-1}$ to $18 \mathrm{~L}^{\mathrm{min}} \mathrm{m}^{-1}$ was used for the automated welding. The root pass was made with purge gas (Ar), and the welding was performed with a pulsed current and a positive-polarity electrode $(\mathrm{CC}+)$ so that all welding passes were carried out with the droplet-metal transfer.

Table 1. Chemical composition of UNS S32205 (wt\%) duplex stainless steel plate and requirements established by ASTM A240 $0^{30}$.

\begin{tabular}{cccc}
\hline Element & Sample & ASTM A240 & $\begin{array}{c}\text { ER2209 } \\
\text { electrode }\end{array}$ \\
\hline $\mathrm{C}$ & $0.017 \pm 0.002$ & $<0.030$ & $<0.020$ \\
\hline $\mathrm{Si}$ & $0.38 \pm 0.01$ & $<1.00$ & 0.05 \\
\hline $\mathrm{Mn}$ & $1.44 \pm 0.02$ & $<2.00$ & 1.60 \\
\hline $\mathrm{P}$ & $0.026 \pm 0.002$ & $<0.03$ & $<0.02$ \\
\hline $\mathrm{S}$ & $<0.002$ & $<0.020$ & $<0.015$ \\
\hline $\mathrm{Cr}$ & $22.3 \pm 0.3$ & 22.0 to 23.0 & 23.0 \\
\hline $\mathrm{Ni}$ & $5.79 \pm 0.07$ & 4.50 to 6.50 & 9.00 \\
\hline $\mathrm{Mo}$ & $3.08 \pm 0.03$ & 3.00 to 3.50 & 3.20 \\
\hline $\mathrm{N}$ & $0.16 \pm 0.03$ & 0.14 to 0.20 & 0.16 \\
\hline $\mathrm{PREN}$ & 35.04 & 34.14 to 37.75 & 36.12 \\
\hline
\end{tabular}


The welding of the joints used three levels of welding energy: standard condition, $1.0 \mathrm{~kJ} . \mathrm{mm}^{-1}$, following the Petrobras N-133 standard $^{23}$; low-energy condition, $0.5 \mathrm{~kJ} . \mathrm{mm}^{-1}$, intending to cause ferrite disproportion in the melted zone (MZ); and high-energy condition, $3.5 \mathrm{~kJ} . \mathrm{mm}^{-1}$. This latter condition was performed with two consecutive passes to cause the precipitation of the sigma phase in the heat-affected zone (HAZ). As the amount of deposited material is proportional to the heat input (see Equation 2) ${ }^{22}$, the total number of welding passes was equal to ten on $0.5 \mathrm{~kJ} . \mathrm{mm}^{1}$ (one root and nine filling passes); six on $1.0 \mathrm{~kJ} . \mathrm{mm}^{-1}$ (one root and five filling passes); and three on $3.5 \mathrm{~kJ} \mathrm{~mm}^{-1}$ (one root and two filling passes).

$$
H=\eta \frac{E I}{v}
$$

Where: $H$ is the heat input $\left(\mathrm{J}^{\mathrm{mm}} \mathrm{m}^{-1}\right), E$ is the voltage (V), $I$ is the current $(\mathrm{A}), v$ is the welding speed $\left(\mathrm{mm} \cdot \mathrm{s}^{-1}\right)$, and the $\eta$ is the welding efficiency. The welding efficiency is dimensionless, with a range between 0.6 and 1.0.

The metallographic preparation involved mechanical grinding using sandpaper (following the \#340, \#600 and \#1200 sequence). The polishing used $3 \mu \mathrm{m}$ and $1 \mu \mathrm{m}$ diamond paste suspension. Final polishing was carried out for $10 \mathrm{~min}$ using $0.05 \mu \mathrm{m}$ alumina suspension solution. The polished samples were electrolytically etched in $10 \%$ oxalic acid or potassium hydroxide $(\mathrm{KOH})$ solutions. For both etchings, a voltage of $10 \mathrm{~V}$ was applied for $30 \mathrm{~s}$, as previously described $^{11,19,20,28}$. The metallographic examinations were performed in the three regions of the weld beads: molten zone (MZ), bound zone (BZ) and heat-affected zone (HAZ) of the welded joints as described in Figure 1. As-welded samples were characterised by optical and SEM (FEI Quanta 400 SEM) using SEI and BEI imaging. The latter used a voltage of $20 \mathrm{kV}$ and a working distance of $10 \mathrm{~mm}$.

The HAZ region was sometimes divided into two distinct zones: the HAZHT zone corresponds to a heat-affected region exposed to higher temperatures localised closer to the molten zone (MZ). The HAZLT zone corresponds to a heat-affected region exposed to a lower temperature, closer to the base metal. The research group responsible for producing the welded samples performed EBSD examinations for all weld joints ${ }^{33}$, and they did not observe the sigma phase in any region of the three welding conditions. A quantitative analysis of the proportion of $\alpha / \gamma$ phases in the welded metal was performed using an image segmentation program via neural networks SVRNA $®$ : three planes of the welded joints (see Figure 2) were sampled and metallographically examined, and optical microscope images (500X magnification) were scanned in.

The tensile tests were performed with rectangular section specimens: $(25 \times 10) \mathrm{mm}^{2}$ and parallel section of $80 \mathrm{~mm}$, according to ISO $6892^{34}$. The location of the weld bead in the specimens was approximately in the middle of the transversal section. The tensile tests were performed on a calibrated Instron ${ }^{\circledR} 300 \mathrm{DX}-\mathrm{C} 3 \mathrm{~A}-\mathrm{G} 1 \mathrm{E}$ static hydraulic universal testing machine with a $95 \%$ confidence interval. For each welding condition, only one sample was tested. Extensometers were not used to prevent the device's damage in case of an unexpected brittle rupture of the welded

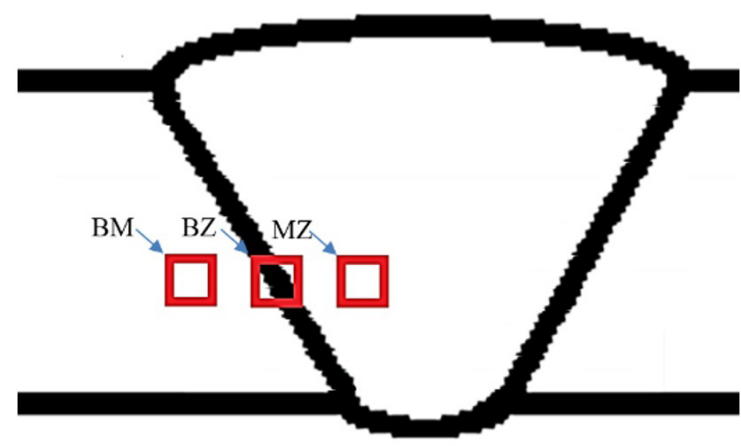

Figure 1. Schematic representation of the regions analysed from the weld macrography. BM represents the base metal, BZ represents the bonding zone, and MZ represents the molten zone. The heat-affected zones are the regions between the bounding and base-metal zones.

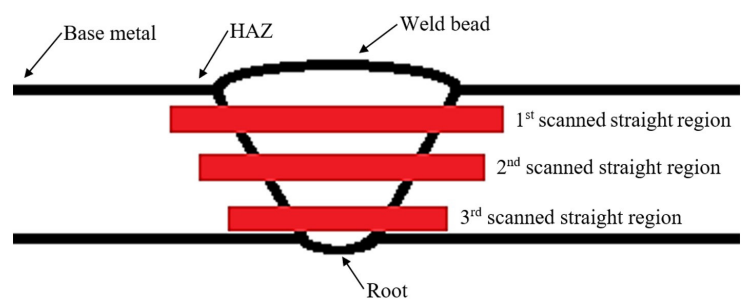

Figure 2. Schematics of the sites where the qualitative analysis of phases present in the welded joints was performed.

samples. Method of ISO 6892 B (stress control) with a strain range $4\left(0.0067 \mathrm{~s}^{-1} \pm 20 \%\right)$ was used. The stressstrain curve was obtained using the force measurement from the load cell and the cross-sectional area to calculate the stress, and the original distance between the grips was used to calculate strain throughout the test. The offset yield strengths were determined from the stress-strain curves. The yield stress corresponds to the intersection of the stress-strain curve and a line parallel to its straight-line portion offset by $0.2 \%$ strain.

Intergranular-corrosion susceptibility analyses were performed using ASTM A262 practice $\mathrm{A}^{29}$. Although this standard is directed to austenitic-stainless steels, some authors have performed practice A for duplex stainless steels ${ }^{8,16,17}$. BZ-specimens with the approximate dimensions of $(10 \times 10) \mathrm{mm}^{2}$ were extracted with the fusion line localised at the centre of the specimen. As mentioned before, these samples were metallographically prepared. A $10 \%$ oxalic acid solution and a current density of $1 \mathrm{~A} . \mathrm{cm}^{-2}$ was applied to the exposed surface for $90 \mathrm{~s}$ at room temperature. For each welding condition, only one sample was tested.

Pitting-corrosion-susceptibility tests were performed according to ASTM G48 practice $\mathrm{A}^{24}$. Two specimens of dimensions $(20 \times 35 \times 10) \mathrm{mm}^{3}$ with a $3.5 \mathrm{~mm}$ hole at the top were used (see Figure 3). Specimens were extracted to keep the weld bead at the centre of the $(10 \times 35) \mathrm{mm}^{2}$ transversal surface. For each welding condition, only one sample was tested. The specimens were immersed in a $10 \%$ (mass fraction) hexahydrate ferric chloride solution for $72 \mathrm{~h}$ at $50^{\circ} \mathrm{C}$ in a way that all the specimen's faces were 
in contact with the solution. After the pitting-corrosion test, the specimen's transversal section face (demarcated by the black arrow in Figure 3) was metallographically prepared, and electrolytically etched in a $10 \%$ oxalic acid solution. Macrographic images were obtained on a Leica ${ }^{\circledR}$ M205C stereoscope, and the micrographs of the pits were acquired on an Olympus ${ }^{\circledR}$ BX51M light-field optical microscope (OM). The maximum pitting rate was calculated by Equation 3 according to NACE SP0775 35 , using the optical microscope.

$P R=\frac{365 \cdot Y}{t}$

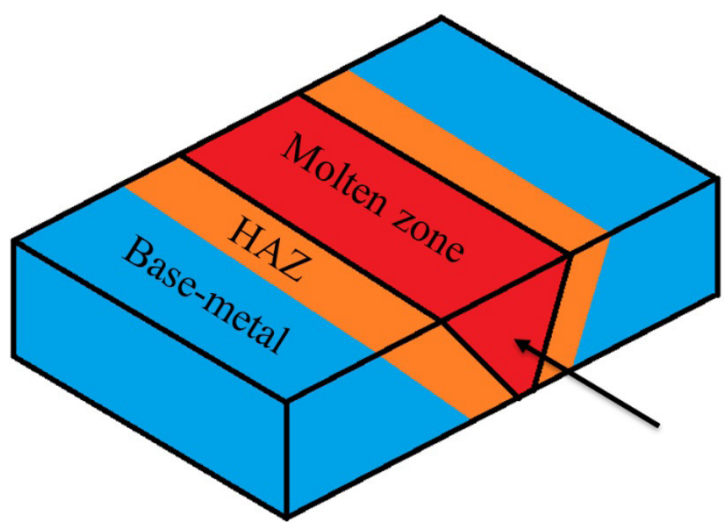

Figure 3. Schematic representation of the pitting corrosion susceptibility test specimen. The black arrow represents the face observed in the results section.
Where: $P R$ is the pitting rate (in mm.year ${ }^{-1}$ ), $Y$ is the most profound pit depth ( $\mathrm{mm})$, and $t$ is the test time (in days).

The topography of the corroded specimens was observed in an SEM (FEI Quanta 400 SEM using an accelerating voltage of $20 \mathrm{kV}$ and a beam current of about $1 \mathrm{nA}$ ). Spot, area and line-mode EDS microanalyses were performed. The EDS microanalyses on the three different weld regions (MZ, BZ and HAZ) were carried out on three areas of approximately (100x100) $\mu \mathrm{m}$, applying dwell times between $100 \mathrm{~s}$ and $120 \mathrm{~s}$. A hypothesis testing - analysis of variance (ANOVA) - was performed to compare the EDS microanalyses results for all welding conditions and welding regions.

\section{Results and Discussion}

The microstructure of the UNS S32205 plate (BM) (longitudinal rolling section) is shown in Figure 4a. Only two phases can be identified: ferrite (dark regions) and austenite (light regions). A 3D assembly with the rolling direction is shown in Figure 4b. Despite having undergone the solubilisation heat treatment at $1100{ }^{\circ} \mathrm{C}$, the elongated microstructure from the rolling process (showing plate-like austenite) is still present

The macrographs of the welded joints are shown in Figures $5 \mathrm{a}$ to $5 \mathrm{c}$. The $0.5 \mathrm{~kJ} . \mathrm{mm}^{-1}$ macrostructure showed a higher number of passes; therefore, a smaller amount of material was deposited per pass than the welded joints with higher energy. The microstructure inside each welding pass presented directional growth (solidification growth perpendicular to the heat extraction); see Figure 5a. The $1.0 \mathrm{~kJ} . \mathrm{mm}^{-1}$ weld bead presents seven passes with elongated shapes, characteristic of the welding process

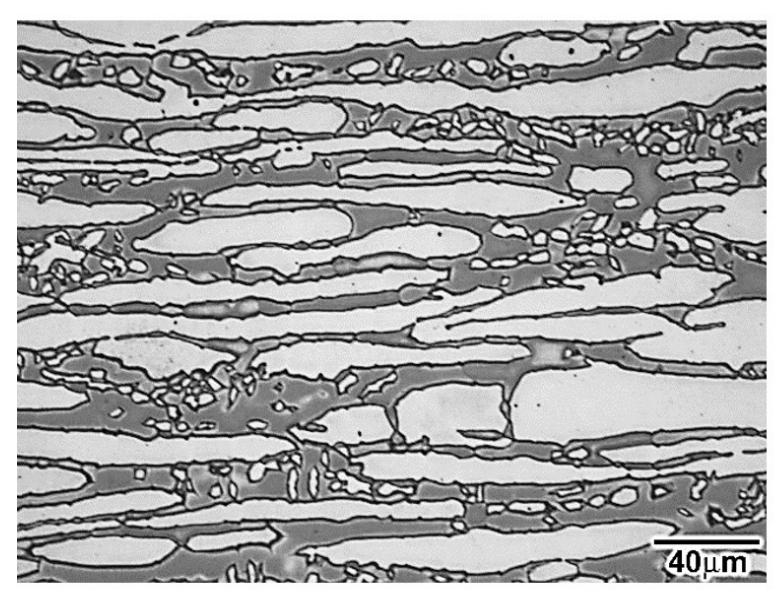

(a)

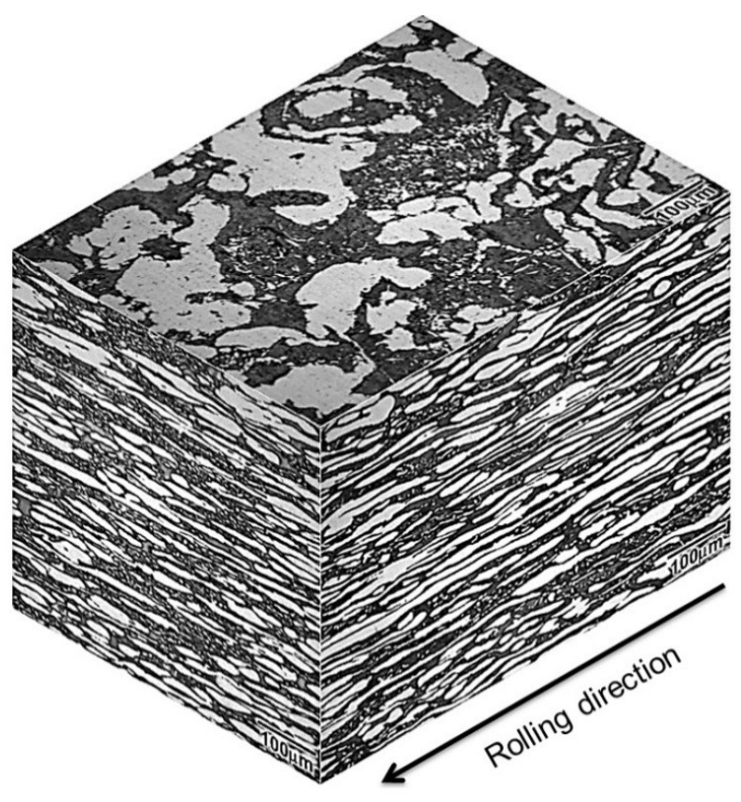

(b)

Figure 4. Cross-section microstructure of the UNS S32205 duplex stainless steel plate (a) and 3D assembly with the rolling direction (b) ${ }^{20,21}$. The microstructure comprises a ferritic matrix $(\alpha)$, dark phase, and elongated austenite $(\gamma)$ precipitates, light phase. Ferrite content of $51 \%$. OM, electrolytic attack in $\mathrm{KOH}$ solution. 
using active gas, see Figure $5 \mathrm{~b}$. The $3.5 \mathrm{~kJ} . \mathrm{mm}^{-1}$ weld bead showed a coarser macrostructure, but the growth was "less directional". Both features indicate a higher-heat input of the molten metal and a more significant extension of the heat-affected zone (see the darker band close to the molten zone, see Figure 5c).

The proportion of ferrite in the MZ, HAZHT and HAZLT is shown in Table 2. The MZ of the $0.5 \mathrm{~kJ} . \mathrm{mm}^{-1}$ welded joint featured about $70 \%$ of ferrite. In the other extreme, the $3.5 \mathrm{~kJ} . \mathrm{mm}^{-1} \mathrm{MZ}$ presented maximum ferrite content of $54 \%$. The cooling rate influences the proportion of austenite in the MZ: slower cooling rates from the ferrite field promote the austenite nucleation and growth. Therefore, the welding processes with higher energies presented a slower cooling rate, resulting in a higher proportion of austenite $\mathrm{e}^{3,23,36}$. The HAZHT of $1.0 \mathrm{~kJ} . \mathrm{mm}^{-1}$ and $3.5 \mathrm{~kJ} . \mathrm{mm}^{-1}$ weldments showed lower austenite contents than the respective $\mathrm{MZ}$, since the addition metal contained higher nickel content (see Tables 1 and 2). The filler contains a higher amount of austenitising elements, which facilitate the nucleation and the growth of austenite in the MZ rea $^{3}$. The ferrite content in the $\mathrm{MZ}$ of the $0.5 \mathrm{~kJ} . \mathrm{mm}^{-1}$ welded joint was higher than in HAZHT due to the high cooling rate imposed by the low welding energy heat input ${ }^{1}$.

Figures $6 \mathrm{a}$ to $6 \mathrm{c}$ show the $\mathrm{MZ}$ microstructures for the three welding conditions. The average size of the austenite precipitates follows the trend of heat input; the higher the heat input, the coarser the austenite precipitation ${ }^{2}$. According to the Dubé classification $^{37-39}$, the microstructure comprises primary Widmanstätten austenite plates, secondary Widmanstätten austenitic sawteeth and grain boundary allotriomorphic austenite.

Figures $7 \mathrm{a}$ to $7 \mathrm{c}$ show the microstructures of the bounding zone (interface between the MZ and the heat-affected zone, also known as a high-temperature region of the HAZ or HAZHT) for the three welding conditions. The austenite morphology changes in the $0.5 \mathrm{~kJ} . \mathrm{mm}^{-1}$ and $1.0 \mathrm{~kJ} . \mathrm{mm}^{-1}$ welds (see Figures $7 \mathrm{a}$ and $7 \mathrm{~b}$ ). During heating, the base-metal austenite partially dissolves at elevated temperatures, but during cooling, some of the dissolved austenite grows back in a more acicular morphology ${ }^{40}$. The shades of grey in the ferrite matrix in the samples featuring a more rapid cooling rate (see Figures $7 \mathrm{a}$ and $7 \mathrm{~b}$ ) might suggest solute segregation caused by the partial dissolution of the austenite in the HAZ. In some regions, secondary Widmanstätten austenitic sawtooth morphology is noted ${ }^{37,38}$. Finally, the transition region between MZ and HAZHT shows epitaxial growth at the solid/liquid interface. For the $3.5 \mathrm{~kJ} . \mathrm{mm}^{-1}$ weld (see Figure 7c), the HAZHT remained at a high temperature for longer, causing partial austenite dissolution and ferritic grain growth. During the comparatively slower cooling, a

Table 2. Ferrite content of welded joints with $0.5 \mathrm{~kJ} . \mathrm{mm}^{-1}, 1.0 \mathrm{~kJ} . \mathrm{mm}^{-1}$ and $3.5 \mathrm{~kJ} . \mathrm{mm}^{-1}$ in the different regions analysed: molten zone (MZ); heat-affected zone of high temperature (HAZHT); and heat-affected zone of low temperature (HAZLT).

\begin{tabular}{cccc}
\hline \multirow{2}{*}{ Region } & \multicolumn{3}{c}{ Ferrite content $(\%)$} \\
\cline { 2 - 4 } & $0.5 \mathrm{~kJ} \cdot \mathrm{mm}^{-1}$ & $1.0 \mathrm{~kJ} \cdot \mathrm{mm}^{-1}$ & $3.5 \mathrm{~kJ} \cdot \mathrm{mm}^{-1}$ \\
\hline MZ & $70(4)$ & $63(3)$ & $54(3)$ \\
\hline HAZHT & $68(3)$ & $65(3)$ & $59(3)$ \\
\hline HAZLT & $57(3)$ & $60(3)$ & $55(3)$ \\
\hline Base metal & & $51(3)$ & \\
\hline
\end{tabular}

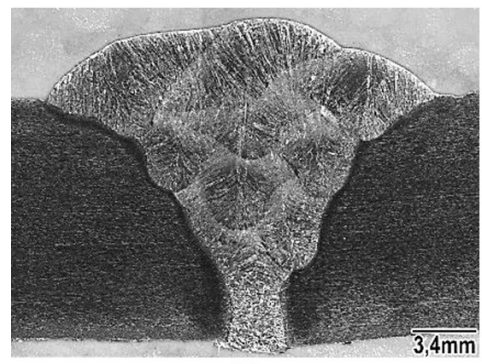

(a)

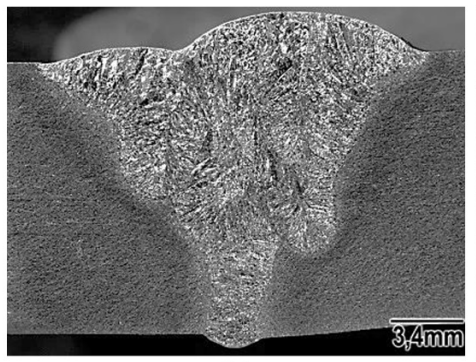

(b)

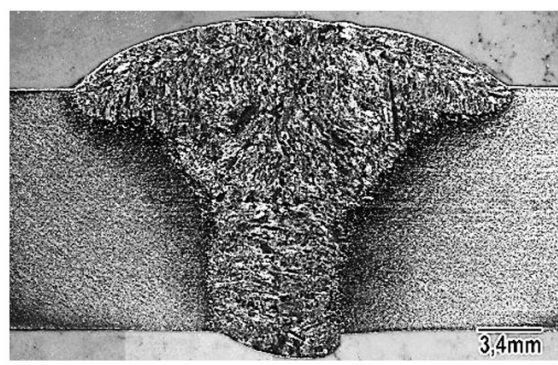

(c)

Figure 5. Macrography of weld beads performed with the following welding energies: (a) $0.5 \mathrm{~kJ} . \mathrm{mm}^{-1}$, (b) $1.0 \mathrm{~kJ} . \mathrm{mm}^{-1} \mathrm{e}$ (c) $3.5 \mathrm{~kJ} . \mathrm{mm}^{-1}$. $\mathrm{OM}$, electrolytic etching in oxalic acid solution.

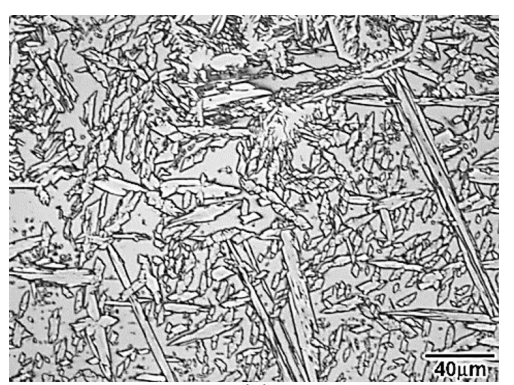

(a)

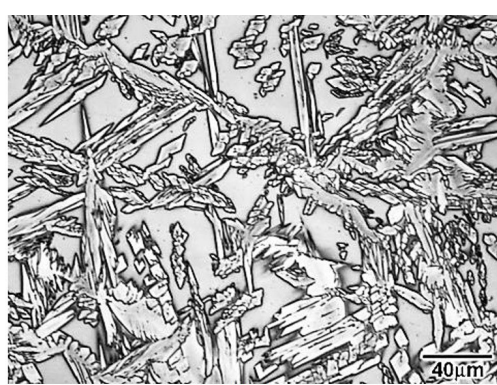

(b)

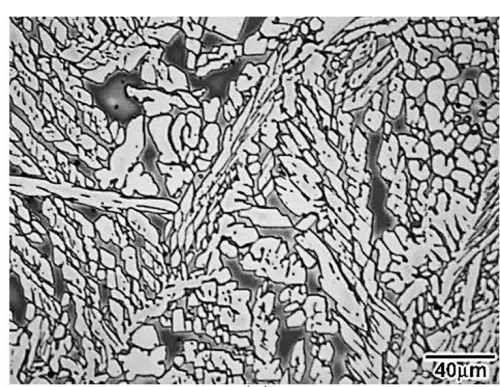

(c)

Figure 6. Microstructure of the molten zone (MZ). (a) $0.5 \mathrm{~kJ} . \mathrm{mm}^{-1}$ with a ferrite content of $70 \%$ (matrix) and acicular austenite precipitation; (b) $1.0 \mathrm{~kJ} . \mathrm{mm}^{-1}$ with a ferrite content of $63 \%$ (matrix) and acicular austenite precipitation; (c) $3.5 \mathrm{~kJ} . \mathrm{mm}^{-1}$ with a ferrite content of $54 \%$ (matrix) and coarser acicular austenite precipitation. OM, electrolytic etching in $\mathrm{KOH}$ solution. 
higher proportion of austenite reprecipitates with a coarser morphology, which can be observed qualitatively in Figure 7c. All HAZHT microstructures showed austenite allotriomorphic grain boundary and primary Widmanstätten austenite plates $^{37,38}$.

Figures $8 \mathrm{a}$ to $8 \mathrm{c}$ show the microstructure of the HAZLT of the three welding conditions. For the $0.5 \mathrm{~kJ}^{\mathrm{m}} \mathrm{mm}^{-1}$ and $1.0 \mathrm{~kJ} . \mathrm{mm}^{-1}$ weldings, the austenite reveals a morphological alteration in relation to the base metal. This change is due to austenite dissolution at high temperatures and austenite reprecipitation and/or growth during slow cooling ${ }^{40}$. The shades of grey in the ferrite matrix in the samples featuring a more rapid cooling rate (see Figures $8 \mathrm{a}$ and $8 \mathrm{~b}$ ) suggest solute segregation caused by the partial dissolution of the austenite in the HAZ during the welding process. The HAZLT austenite shows a morphology similar to the base metal, but featuring a lesser degree of austenite dissolution (exposure to lower temperatures) and the presence of secondary Widmanstättenplate austenite (formed during the cooling of the welding process), see Figures $8 \mathrm{a}$ and $8 \mathrm{~b}$. For the $1.0 \mathrm{~kJ} . \mathrm{mm}^{-1}$ welding, for example, the presence of secondary Widmanstätten austenite sawtooth is observed but less frequently than in the HAZHT region. The microstructure of the $3.5 \mathrm{~kJ} . \mathrm{mm}^{-1}$ welding shows grain-boundary allotriomorphic and primary Widmanstättenplate austenite in a ferritic matrix (dark phase). Additionally, the ferrite grain size is comparatively larger (see Figure 8c).
The tensile test results of the welded joints are shown in Table 3. All tensile specimens broke in the base metal region (away from the weld bead and HAZ), which features a lower ferrite proportion when compared to MZ, HAZHT and HAZLT (see Table 2). The fracture position suggests that the higher proportion of ferrite in the microstructure increases the yield and the tensile strengths of the duplex stainless steel, which is in agreement with the tensile properties shown in Figure $9^{41}\left(\operatorname{apud}^{2}\right)$. The welding process with energy of $3.5 \mathrm{~kJ} . \mathrm{mm}^{-1}$ (a condition apparently more prone to embrittlement by intermetallic Cr-rich phase precipitation) ${ }^{3,9,23}$ showed higher yield strength, ultimate tensile strength (UTS) and elongation values than the other specimens. Nevertheless, the tensile properties of the remaining welded joints did not vary more than their respective standard deviations and presented values close to those of the base metal.

Figures 10a to $10 \mathrm{c}$ show the microstructure of the bonding zone (BZ) for all weldings using backscattered electrons imaging. These BEI images did not reveal intermetallic precipitates with high chromium content, such as the sigma phase, even for the welding at $3.5 \mathrm{~kJ} . \mathrm{mm}^{-1}$ energy (BEI resolution is around $500 \mathrm{~nm}$ ). These results agree with the observations made by the welder's report ${ }^{33}$, indicating that the kinetics of sigma phase precipitation was not rapid enough to promote sigma phase precipitation for the most critical condition. Additionally, Figures 10a to 10c show

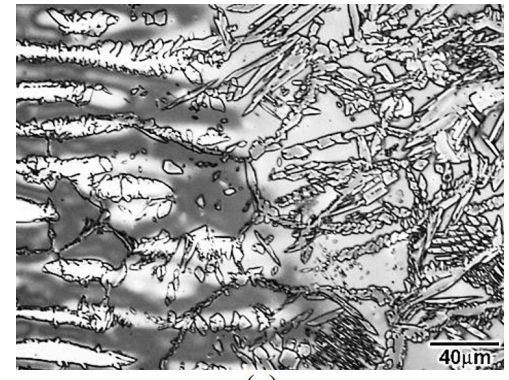

(a)

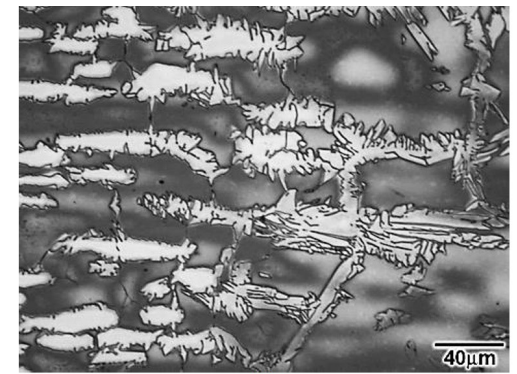

(b)

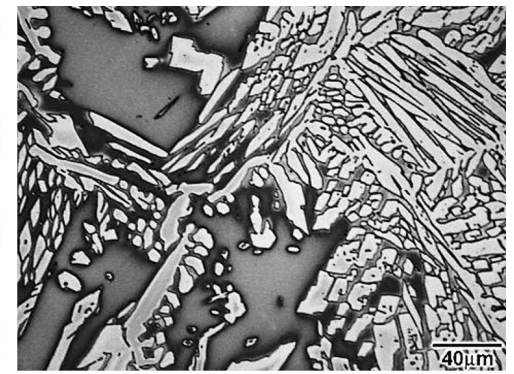

(c)

Figure 7. Microstructure of the bounding zone region and the heat-affected zone with high temperature (HAZHT). (a) $0.5 \mathrm{~kJ} . \mathrm{mm}^{-1}$ with a ferrite content of $68 \%$ and austenite precipitation featuring sawtooth interface; (b) $1.0 \mathrm{~kJ} . \mathrm{mm}^{-1}$ with a ferrite content of $65 \%$ and austenite precipitation with a sawtooth interface; (c) $3.5 \mathrm{~kJ} . \mathrm{mm}^{-1}$ with a ferrite content of $59 \%$ (matrix) and austenite precipitation (parallel plates). The shades of grey in the ferrite matrix suggest solute segregation caused by the partial dissolution of the austenite during the welding process. OM, electrolytic etching in $\mathrm{KOH}$ solution.

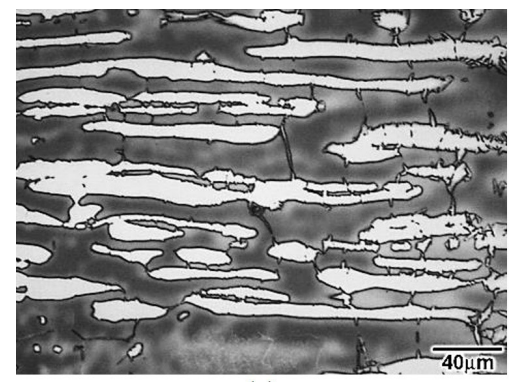

(a)

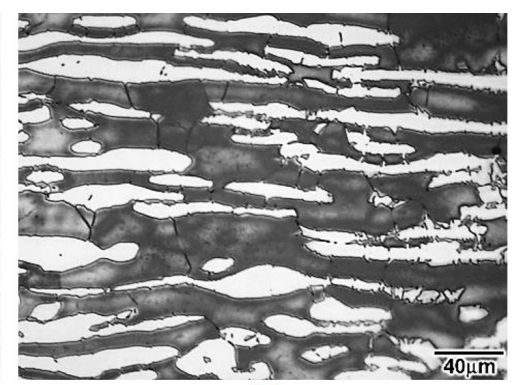

(b)

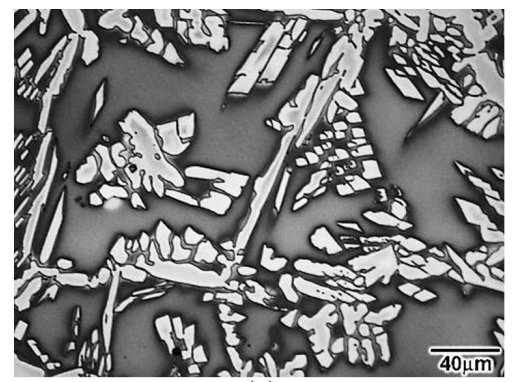

(c)

Figure 8. Microstructure of the heat-affected zone and the heat-affected zone with low temperature (HAZLT). (a) $0.5 \mathrm{~kJ}^{\mathrm{m}} \mathrm{mm}^{-1}$ with a $^{-1}$ ferrite content of $57 \%$ (matrix) and plate-like austenite precipitates. (b) $1.0 \mathrm{~kJ} . \mathrm{mm}^{-1}$ with a ferrite content of $60 \%$ (matrix) and plate-like austenite precipitates. (c) $3.5 \mathrm{~kJ} . \mathrm{mm}^{-1}$ with a ferrite content of $55 \%$ (matrix) and plate-like austenite precipitates. The shades of grey in the ferrite matrix suggest solute segregation caused by the partial dissolution of the austenite during the welding process. OM, electrolytic etching in $\mathrm{KOH}$ solution. 
Table 3. Mechanical properties of the welded joints and base metal obtained from tensile testing.

\begin{tabular}{ccccc}
\hline \multirow{2}{*}{ Mechanical properties } & \multirow{2}{*}{ Base metal } & \multicolumn{3}{c}{ Welded joints } \\
\cline { 3 - 5 } & & $0.5 \mathrm{~kJ}^{\mathrm{m} \mathrm{mm}^{-1}}$ & $1.0 \mathrm{~kJ}_{\mathrm{mm}} \mathrm{m}^{-1}$ & $3.5 \mathrm{~kJ} \cdot \mathrm{mm}^{-1}$ \\
\hline Yield strength (MPa) & $501 \pm 3$ & $484 \pm 3$ & $504 \pm 3$ & $530 \pm 3$ \\
\hline Tensile strength (MPa) & $706 \pm 4$ & $670 \pm 4$ & $694 \pm 4$ & $722 \pm 4$ \\
\hline Elongation (\%) & $33 \pm 1$ & $24 \pm 1$ & $27 \pm 1$ & $31 \pm 1$ \\
\hline
\end{tabular}

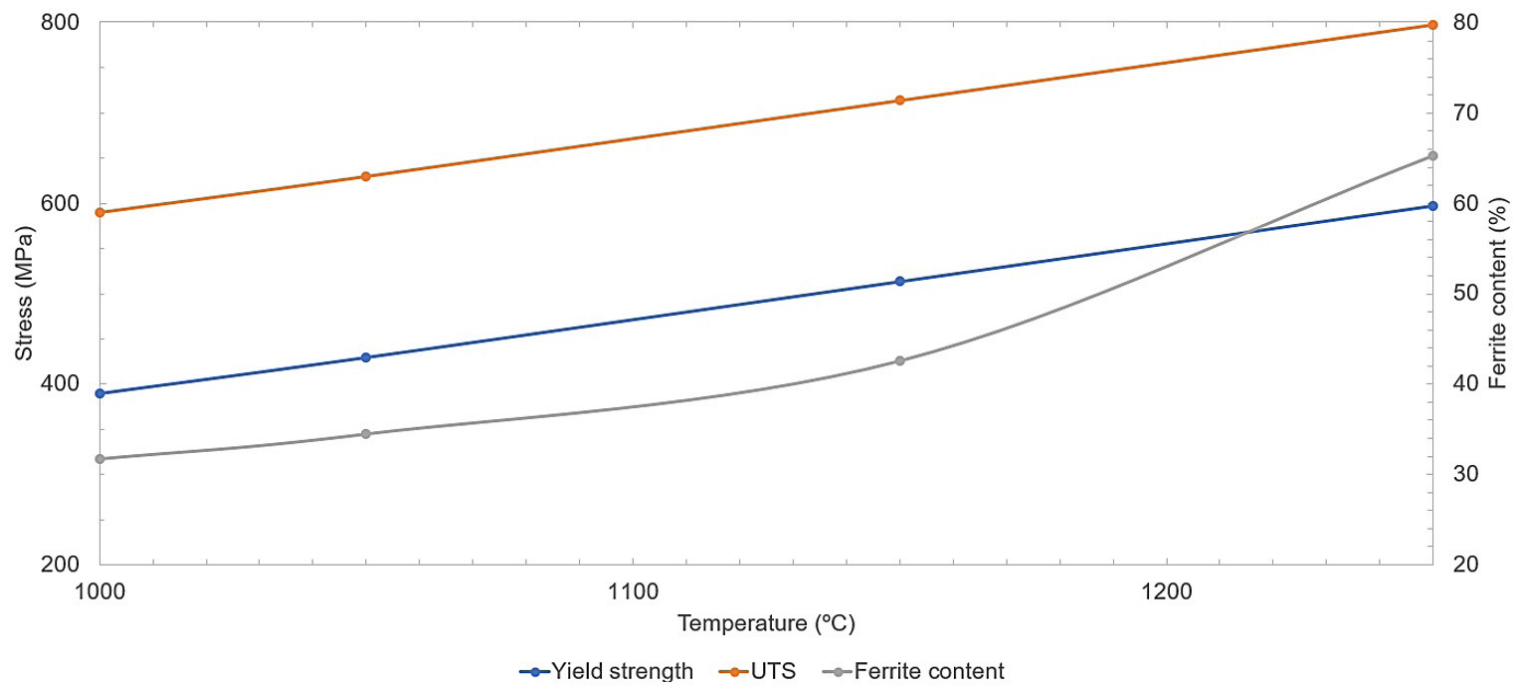

Figure 9. General results from ${ }^{41}\left(\operatorname{apud}^{2}\right)$. Relationship between the percentage of ferrite in the microstructure of duplex stainless-steel and its mechanical properties: ultimate tensile strength (UTS), yield strength and ferrite content (\%). Figure adapted from ${ }^{41}\left(\operatorname{apud}^{2}\right)$.

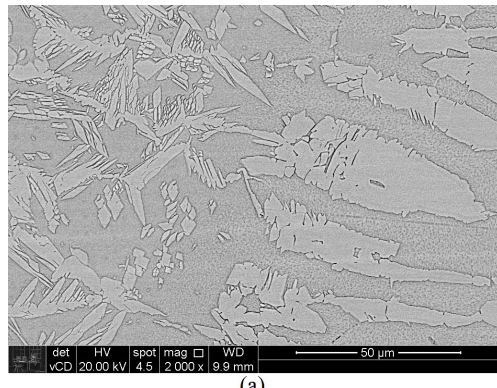

(a)

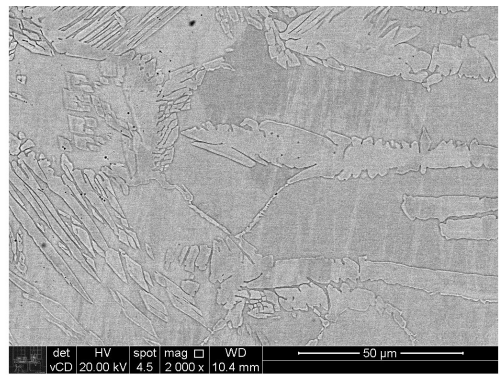

(b)

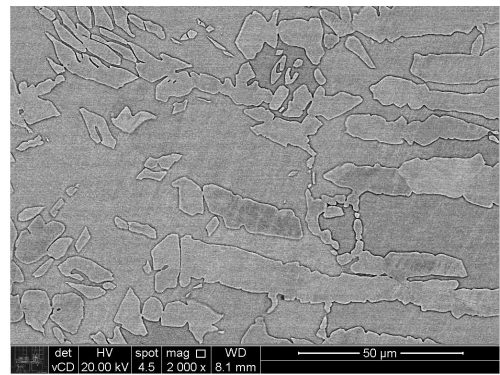

(c)

Figure 10. Duplex microstructure of the boundary zone welded with the following welding energies: (a) $0.5 \mathrm{~kJ} . \mathrm{mm}^{-1}$, (b) $1.0 \mathrm{~kJ} . \mathrm{mm}^{-1}$ e (c) $3.5 \mathrm{~kJ}_{\mathrm{mm}} \mathrm{m}^{-1}$. The matrix is the ferrite phase, and the precipitates are the austenite phase. The microstructures show the differences in the austenite morphology. The lower welding energy presented a steep morphological gradient and acicular austenite (sawtooth). In comparison, welding with higher energies showed a smother morphological gradient, with coarser austenite precipitation. There is no indication of the sigma phase precipitates (BEI resolution is around $500 \mathrm{~nm}$ ). SEM, BEI, electrolytic etching in oxalic acid solution.

similar morphological information to the light microscopy (see Figures 7 a to $7 \mathrm{c}$ ).

The EDS line analysis results between austenite and ferrite phases at the $1.0 \mathrm{~kJ} . \mathrm{mm}^{-1}$ HAZHT are shown in Figures $11 \mathrm{a}$ and $11 \mathrm{~b}$. The austenite presented higher nickel and lower molybdenum contents than the ferrite. Additionally, these results suggest a compositional gradient in the ferrite matrix, indicating higher $\mathrm{Ni}$ and lower $\mathrm{Cr}$ and $\mathrm{Mo}$ contents close to the partially dissolved austenite. These results confirm previous observations proposing solute segregation in the ferrite (see Figures 7a, b and 8a, b) for the more rapidly cooled samples. Still, a more definitive analysis, such as APT
(Atom Probe Tomography), is needed to confirm the solute segregation in the ferrite due to the austenite dissolution.

EDS point-mode analyses in the ferrite and austenite phases of the HAZ regions indicates that molybdenum (ferritising alloying element) partitions preferentially into the ferrite independent of the welding energy $(3.3(0.1) \%$ in the ferrite and $2.1(0.1) \%$ in the austenite), confirming previous results $^{42}$. Nickel partitions preferentially in austenite, also independent of the welding energy $(5.2(0.2) \%$ in ferrite and $6.9(0.5) \%$ in austenite). Additionally, the results of the EDS area-mode analyses on the three different weld regions under all conditions are shown in Table 4 indicate that: 


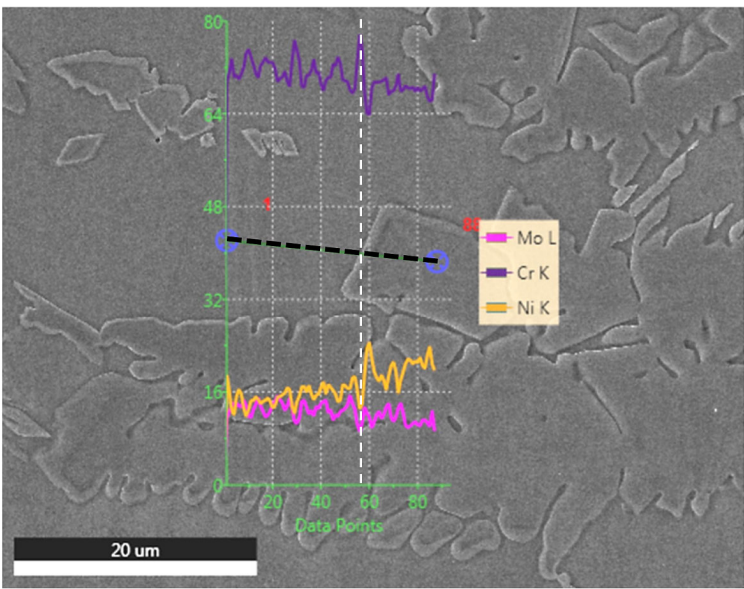

(a)

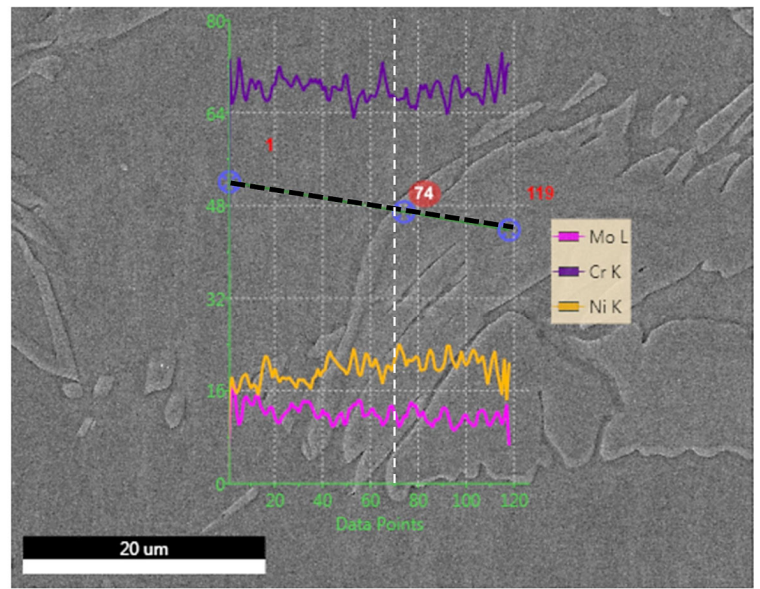

(b)

Figure 11. Results of the EDS line analysis (the black line shows the EDS line analysis and the dotted white line shows the position of the austenite/ferrite interface) between $\alpha$ and $\gamma$ phases at the HAZHT (a) and (b) $1.0 \mathrm{~kJ} . \mathrm{mm}^{-1}$. The austenite presented higher nickel and lower molybdenum contents. These results suggest a compositional gradient in the ferrite matrix, indicating higher $\mathrm{Ni}$ and lower $\mathrm{Cr}$ and Mo content close to the partially dissolved austenite. These results confirm previous observations suggesting solute segregation in the ferrite (see Figures 7 and 8). SEM, BEI, electrolytic etching in oxalic acid solution.

Table 4. Results of the EDS analysis on the different weld regions.

\begin{tabular}{|c|c|c|c|c|}
\hline Welding energy & Zone & $\mathrm{Cr}$ & $\mathrm{Ni}$ & Mo \\
\hline \multirow[t]{3}{*}{0.5 kJ.mm ${ }^{-1}$} & MZ & $24.2(1.2)$ & $7.3(0.4)$ & $2.9(0.6)$ \\
\hline & BZ & $23.6(0.4)$ & $6.1(0.3)$ & $2.6(0.1)$ \\
\hline & HAZ & $23.6(0.3)$ & $5.4(0.3)$ & $2.8(0.5)$ \\
\hline \multirow[t]{3}{*}{$1 \mathrm{~kJ} . \mathrm{mm}^{-1}$} & MZ & $24.9(0.4)$ & $7.4(0.1)$ & $2.5(0.2)$ \\
\hline & BZ & $24.4(0.3)$ & $6.3(0.2)$ & $2.5(0.1)$ \\
\hline & HAZ & $24.5(0.5)$ & $5.2(0.2)$ & $2.3(0.2)$ \\
\hline \multirow[t]{3}{*}{3.5 kJ.mm ${ }^{-1}$} & MZ & $24.5(0.8)$ & $5.4(0.3)$ & $2.4(0.2)$ \\
\hline & BZ & $23.8(0.8)$ & $5.4(0.6)$ & $2.5(0.2)$ \\
\hline & HAZ & $23.8(1.0)$ & $5.9(0.4)$ & $2.5(0.4)$ \\
\hline
\end{tabular}

a) The nickel content in the MZ was higher than the HAZ for all weld conditions. This characteristic is mainly due to the filler metal's higher nickel content than the MB (see Table 1).

b) The chromium content in the $\mathrm{MZ}$ for the $0.5 \mathrm{~kJ} . \mathrm{mm}^{-1}$ and $3.5 \mathrm{~kJ} . \mathrm{mm}^{-1}$ conditions was higher than in the HAZ. However, a hypothesis testing - analysis of variance (ANOVA) - was performed, showing for all welding conditions and welding regions that $\mathrm{Cr}$ results were equal with $95 \%$ confidence ( $p$-value of $0.62501,0.5657$, and 0.5486 for energies of $0.5 \mathrm{~kJ} . \mathrm{mm}^{-1}$, $1.0 \mathrm{~kJ} . \mathrm{mm}^{-1}$, and $3.5 \mathrm{~kJ} . \mathrm{mm}^{-1}$, respectively).

c) The Mo content in the MZ of $0.5 \mathrm{~kJ} . \mathrm{mm}^{-1}$ was the highest. Again, a hypothesis testing - analysis of variance (ANOVA) - was performed, showing that these Mo values have no statistically significant differences for all welds and regions at $95 \%$ confidence (p-value of 0.4950).

The ASTM A262 practice $\mathrm{A}^{29}$ results are shown in Figures $12 \mathrm{a}$ to $12 \mathrm{~d}$. In general, Figures 12 a to $12 \mathrm{~d}$ show an elongated microstructure with a continuous matrix, as the attack revealed the $\alpha / \gamma$ and $\gamma / \gamma$ interfaces, but not the $\alpha / \alpha$ interface. There is preferential corrosion of the ferrite phase for all conditions. These results agree with Ha et al. ${ }^{43,44}$, who studied the influence of the ferrite to austenite ratio on the pitting corrosion resistance of UNS S32205/S31803 $3^{43}$ and UNS S32101 duplex stainless steels ${ }^{44}$. Different ferrite and austenite proportions were obtained in their studies by isothermal treatments. They observed ${ }^{43,44}$ that ferrite suffered preferential pitting corrosion by a galvanic coupling process with austenite, even when the ferrite phase presented higher pitting resistance equivalent numbers (PRENs).

Figures $12 \mathrm{a}$ to $12 \mathrm{c}$ show elongated austenite grains featuring annealing twinning inside them. The electrolytic etching with $10 \%$ oxalic acid promotes the preferential corrosion of

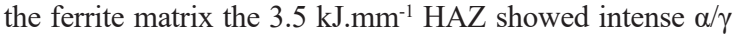
intergranular corrosion (see yellow arrows in Figure 12d). These results suggest that the higher welding energy and lower cooling rate may have promoted the sensitisation of the microstructure along the $\alpha / \gamma$ interfaces without compromising the mechanical integrity of the welding (see Table 3 ).

The experimental results of the tests according to ASTM G48 standard ${ }^{24}$ are shown in Figures 13 a to $13 \mathrm{c}$. The samples extracted from the base metal showed no sign of corrosion, so a macrography was not necessary. These images reveal a different corrosion behaviour according to the welding energy. The welding with less energy $\left(0.5 \mathrm{~kJ} . \mathrm{mm}^{-1}-\right.$ see Figure 13a) showed a high corrosion rate, mainly in the molten zone. This behaviour results from the high ferrite content $(\sim 70 \%$, see Table 2$)$ in this region, recognised as a low corrosion-resistant phase in duplex stainless-steels ${ }^{43}$. The welding with intermediate energy, recommended by the Petrobras N-133 standard ${ }^{23}$ (1.0 kJ.mm ${ }^{-1}$ - see Figure 13b), did not show intense corrosive attack in the molten zone (MZ). This attack was only observed in the MZ near the weld bead interface (BZ). Finally, the welding with higher energy (3.5 kJ.mm ${ }^{-1}$ - Figure 13c) showed intense corrosive attack in HAZ, which features lower ferrite content (see Table 2). This preferential attack in the HAZ suggests that the thermal exposure may have promoted the sensitisation of the microstructure. Further TEM characterisation is 


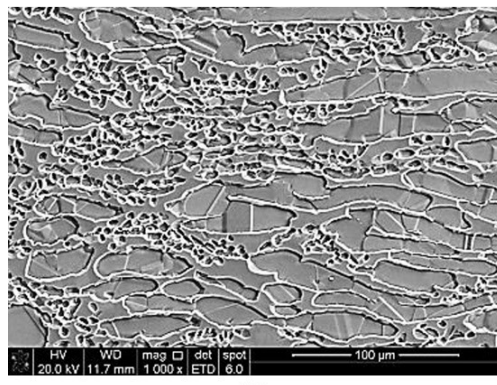

(a)

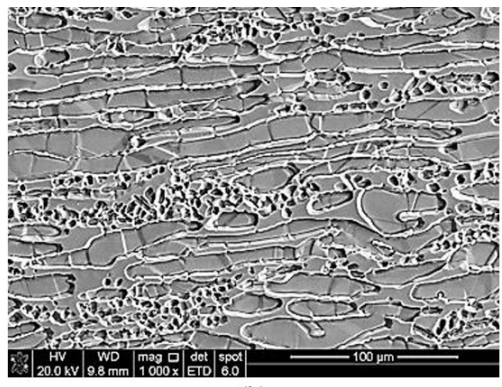

(b)

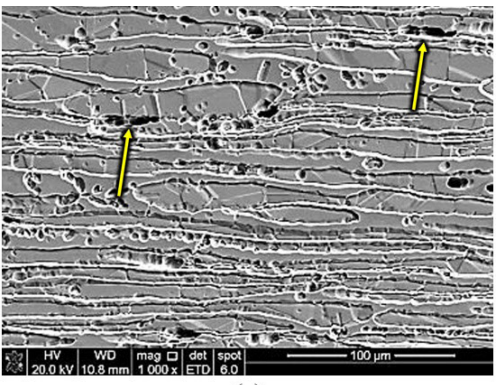

(c)

Figure 12. Results of ASTM A262 practice A. (a) $0.5 \mathrm{~kJ} . \mathrm{mm}^{-1} \mathrm{HAZ}$ (b); $1.0 \mathrm{~kJ} . \mathrm{mm}^{-1} \mathrm{HAZ}$; (c) $3.5 \mathrm{~kJ} . \mathrm{mm}^{-1} \mathrm{HAZ}$. Electrolytic etching

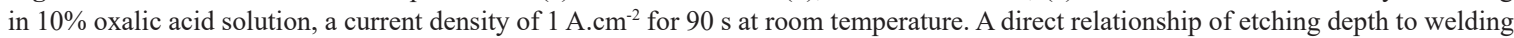
energy is observed. The corrosive attack mainly consumes the ferrite matrix and reveal $\alpha / \gamma$ and $\gamma$ twins interfaces. The ferrite phase suffers

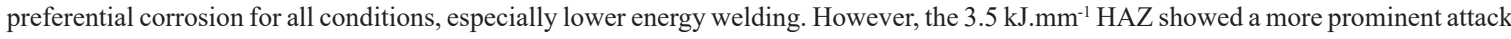
at the $\alpha / \gamma$ interfaces, generating cavities (see yellow arrows). This attack suggests some level of sensitisation at the $\alpha / \gamma$ interfaces. SEM, SEI.

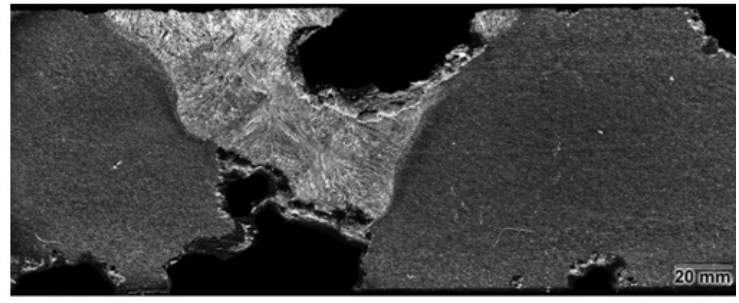

(a)

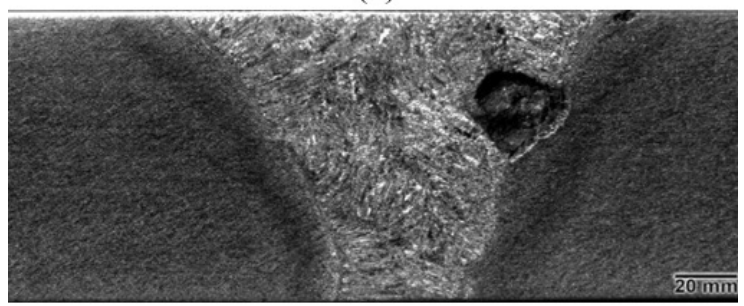

(b)

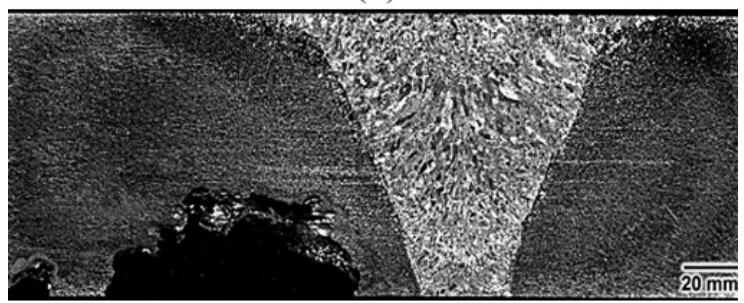

(c)

Figure 13. Macrographs of specimens after the ferric chloride test for $72 \mathrm{~h}$ at $50^{\circ} \mathrm{C}$ for the three different welding energies. (a) $0.5 \mathrm{~kJ}^{\circ} \mathrm{mm}^{-1}$; (b) $1.0 \mathrm{~kJ} \cdot \mathrm{mm}^{-1}$; (c) $3.5 \mathrm{~kJ} \cdot \mathrm{mm}^{-1}$. OM, electrolytic oxalic acid solution etching. The $0.5 \mathrm{~kJ} . \mathrm{mm}^{-1}$ welding showed a greater proportion of corroded region, with more significant corrosion in the $\mathrm{MZ}$ region. The $1.0 \mathrm{~kJ} . \mathrm{mm}^{-1}$ welding showed lesser corrosion in the BZ. The $3.5 \mathrm{~kJ} . \mathrm{mm}^{-1}$ welding did not present corrosion in the $\mathrm{MZ}$ and $\mathrm{BZ}$ regions, but it presented accentuated corrosion in the HAZ. OM, electrolytic etching in oxalic acid solution.

needed to check the presence of the submicron sigma phase precipitation.

The corrosion specimens of ASTM G48 standard ${ }^{24}$ tests exhibited no corrosion products adhered to them. The pitting rate for the specimens was calculated from Equation 3. The results obtained were $3.8 \cdot 10^{3}$ mm.year ${ }^{-1}, 1.1 \cdot 10^{2}$ mm.year $^{-1}$ and $4.1 \cdot 10^{3} \mathrm{~mm} . y e a r^{-1}$ for the welded specimens at $0.5 \mathrm{~kJ} \cdot \mathrm{mm}^{-1}$, $1.0 \mathrm{~kJ} . \mathrm{mm}^{-1}$ and $3.5 \mathrm{~kJ} . \mathrm{mm}^{-1}$, respectively. For the $0.5 \mathrm{~kJ} \mathrm{~mm}^{-1}$ welded joint, there was preferential corrosion in the molten zone, which has the highest percentage of ferrite (see Figure 13a). These results agree with several studies that indicate that a greater amount of ferrite in duplex stainless steel decreases the corrosion resistance of the welded joints ${ }^{18-20}$. For the $1.0 \mathrm{~kJ} . \mathrm{mm}^{-1}$ weldment, corrosion occurred near the bonding zone, see Figure 13b. Paulraj and $\mathrm{Garg}^{27}$ observed higher ferrite content and lowest corrosion rates for welding energies closer to $1.0 \mathrm{~kJ} . \mathrm{mm}^{-1}$. For the $3.5 \mathrm{~kJ} . \mathrm{mm}^{-1}$ weldments (see Figure 13c), the molten zone did not corrode (it has the lowest percentage of ferrite, given the high cooling rate). However, the heat-affected zone underwent an intense corrosive process to its full extent due to its low cooling rate, generating more ferrite in this particular region. Nowacki and Rybicki ${ }^{26}$ observed similar behaviour after ASTM G48 standard ${ }^{24}$ corrosion testing, in which studied the duplex stainless steel UNS S31803 weld joint by SAW with high energy $\left(3.0 \mathrm{~kJ} . \mathrm{mm}^{-1}\right.$ up to $\left.5.0 \mathrm{~kJ} . \mathrm{mm}^{-1}\right)$.

\section{Conclusions}

- The welded UNS S32205 duplex stainless-steels did not show mechanical embrittlement during tensile testing.

- Microssegregation was observed in the HAZ ferrite matrix close to the austenite for the lower energy weldings $\left(0.5 \mathrm{~kJ} . \mathrm{mm}^{-1}\right.$ and $\left.1.0 \mathrm{~kJ} \cdot \mathrm{mm}^{-1}\right)$.

- Optical and scanning electron microscopy did not reveal sigma phase precipitation for all welding conditions and regions. The most critical condition for sigma phase precipitation was created by using two consecutive passes and welding energy of the $3.5 \mathrm{~kJ} . \mathrm{mm}^{-1}$. The latter is higher than recommended by the Petrobras N-133 standard (welding energy of $1.0 \mathrm{~kJ} \cdot \mathrm{mm}^{-1}$ ).

- $\quad$ Practice A of ASTM A262 showed preferential corrosion of the ferrite phase for all conditions.

- $\quad$ Practice A of ASTM A262 for the $3.5 \mathrm{~kJ} . \mathrm{mm}^{-1}$ welded joint revealed severe localised corrosion in HAZ 
$\alpha / \gamma$ interfaces, suggesting submicron precipitation of the sigma phase along these interfaces.

Practice A of ASTM G48 indicated that the welded joint regions featuring a higher proportion of ferrite were more susceptible to localised corrosion.

Localised corrosion occurred preferentially in the weld bead for the $0.5 \mathrm{~kJ} . \mathrm{mm}^{-1}$ welded joint and preferentially in the HAZ for the $3.5 \mathrm{~kJ} . \mathrm{mm}^{-1}$ welded joint. The $1.0 \mathrm{~kJ} . \mathrm{mm}^{-1}$ welded joint was less affected by localised corrosion (ASTM G48 Practice A). These results validate the welding energy requirement of the Petrobras N-133 standard.

\section{Acknowledgements}

The authors would like to thank Petróleo Brasileiro SA for their financial support and Jonas de Carvalho Gomes, Luis Fernando Fiuza Chaves and Bruno de Barros Andrade of the Corrosion and Protection Laboratory of the Institute for Technological Research of the State of São Paulo (IPT) for their assistance in metallography. Additionally, Prof. Cesar R. F. Azevedo would like to thank the Brazilian National Council for Scientific and Technological Development (CNPq) for his research grant (Process: 310583/2020-9).

\section{References}

1. Gunn RN. Duplex stainless steels: microstructure, properties and applications. Cambridge: Woodhead Publishing; 1997.

2. Alvarez-Armas I, Degallaix-Moreuil S. Duplex stainless steels. London: Wiley; 2009.

3. API: American Petroleum Institute. TR 938-C: use of duplex stainless steels in the oil refining industry. Washington, DC: API; 2011.

4. Granta Design. CES Edupack 2017: general information database level 3. Cambridge: Granta Design; 2017.

5. Southwick PD, Honeycombe RWK. Decomposition of ferrite to austenite in 26\%Cr-5\%Ni stainless steel. Met Sci. 1980;14:25361. http://dx.doi.org/10.1179/030634580790426418.

6. Azevedo CRF, Pereira HB, Wolynec S, Padilha AF. An overview of the recurrent failures of duplex stainless steels. Eng Fail Anal. 2019;97. http://dx.doi.org/10.1016/j.engfailanal.2018.12.009.

7. Liao J. Nitride precipitation in Weld HAZs of a duplex stainless steel. ISIJ Int. 2001;41:460-7.

8. Brandi SD, Padilha AF, Stephan W. Corrosion resistance of GTAW and EBW welded joints of DIN W. Nr. 1.4462 (UNS S31803): effect of post-weld-heat-treatment. Mater Des. 1996;3:309-22.

9. Sieurin H, Sandström R. Sigma phase precipitation in duplex stainless steel 2205. Mater Sci Eng A. 2007;444:271-6. https:// dx.doi.org/10.1016/j.msea.2006.08.107.

10. Badji R, Bouabdallah M, Bacroix B, Kahloun C, Bettahar K, Kherrouba N. Effect of solution treatment temperature on the precipitation kinetic of sigma-phase in 2205 duplex stainless steel welds. Mater Sci Eng A. 2008;496:447-54. http://dx.doi. org/10.1016/j.msea.2008.06.024.

11. Pereira HB, Vieira FYM, Santos CAL, Panossian Z. (2016). Efeito do tempo de envelhecimento na resistência a corrosão de aço inoxidável dúplex 2205. Rev. IPT Tecnol. e Inovação., 1(3), 31-40.

12. Pezzato L, Lago M, Brunelli K, Breda M, Calliari I. Effect of the heat treatment on the corrosion resistance of duplex stainless steels. J Mater Eng Perform. 2018;27:3859-68. http://dx.doi. org/10.1007/s11665-018-3408-5.
13. ASM: American Society for Metals. Corrosion: fundamentals, testing, and protection. Material Park: ASM International; 2003.

14. Sathirachinda N, Pettersson R, Pan J. Depletion effects at phase boundaries in 2205 duplex stainless steel characterised with SKPFM and TEM/EDS. Corros Sci. 2009;51:1850-60.

15. IMOA: International Molybdenum Association. Practical guidelines for the fabrication of duplex stainless steel. Londres: IMOA; 2009.

16. Brandi SD. Estudo da soldabilidade do aço inoxidável duplex DIN W. Nr. 1.4462 (UNS 531803) [tese]. São Paulo: Universidade de São Paulo; 1992.

17. Brandi SD, Padilha AF, Wolynec S. Efeito do tratamento térmico pós-soldagem na resistência à corrosão de juntas soldadas de aço inoxidável duplex DIN W. Nr. 1.4462 (UNS S31803). In: $11^{\circ}$ Congresso Brasileiro de Engenharia e Ciência dos Materiais; 1994 Dec 11-14; Águas de São Pedro, São Paulo. Águas de São Pedro: CBECiMat; 1994.

18. Gennari C, Lago M, Bögre B, Meszaros I, Calliari I, Pezzato L. Microstructural and corrosion properties of cold rolled laser welded UNS S32750 duplex stainless steel. Metals. 2018;8:117. http://dx.doi.org/10.3390/met8121074.

19. Pereira H, Azevedo CR. Can the drop evaporation test evaluate the stress corrosion cracking susceptibility of the welded joints of duplex and super duplex stainless steels? Eng Fail Anal. 2019;99:235-47.

20. Pereira HB, Moreira MF, Almeida NL, Batista IP. Influence of stress and temperature on stress corrosion cracking of welded duplex stainless steel joints under drop evaporation test. In: NACE International's CORROSION Conference; 2019; Tennessee, USA. Proceedings. USA: OnePetro; 2019.

21. Pereira HB. Corrosão sob tensão de junta soldada de aço inoxidável duplex: ensaio de flexão em quatro pontos sob gotejamento de solução de água do mar sintética [dissertation]. São Paulo: Universidade de São Paulo; 2018.

22. ASM: American Society for Metals. ASM handbook: welding, brazing, and soldering. Material Park: ASM International; 1993.

23. Petrobras. NTP N-133: Contec SC-26: Soldagem. Brasil: Petrobras; 2015.

24. ASTM: American Society for Testing and Materials. G48: pitting and crevice corrosion resistance of stainless steels and related alloys by use of ferric chloride solution. West Conshohocken: ASTM; 2012.

25. Salinas-Bravo VM, Newman RC. An alternative method to determine critical pitting temperature of stainless steels in ferric chloride solution. Corros Sci. 1994;36:67-77. http:// dx.doi.org/10.1016/0010-938x(94)90109-0.

26. Nowacki J, Rybicki P. Corrosion resistance of SAW duplex joints welded with high heat input. J. Achiev. Mater. Manuf. Eng. 2007;23(2):7-14.

27. Paulraj P, Garg R. Effect of welding parameters on pitting behavior of GTAW of DSS and super DSS weldments. Eng. Sci. Technol. 2016;19:1076-83. http://dx.doi.org/10.1016/j. jestch.2016.01.013.

28. Pereira HB, Panossian Z, Baptista IP, Azevedo CRDF. Investigation of stress corrosion cracking of austenitic, duplex and super duplex stainless steels under drop evaporation test using synthetic seawater. Mater Res. 2019;22(2):e20180211.

29. ASTM: American Society for Testing and Materials. ASTM A262: standard practices for detecting susceptibility to intergranular attack in austenitic stainless steels. West Conshohocken: ASTM; 2010.

30. ASTM: American Society for Testing and Materials. ASTM A240: standard specification for chromium and chromium-nickel stainless steel plate, sheet, and strip for pressure vessels and for general applications. West Conshohocken: ASTM; 2004. 
31. ASTM: American Society for Testing and Materials. ASTM E1019: standard test methods for determination of carbon, sulfur, nitrogen, and oxygen in steel, iron, nickel, and cobalt alloys by various combustion and fusion techniques. West Conshohocken: ASTM; 2011.

32. ASTM: American Society for Testing and Materials. ASTM E572: standard test method for analysis of stainless and alloy steels by wavelength dispersive $\mathrm{x}$-ray fluorescence title spectrometry. West Conshohocken: ASTM; 2013.

33. Miranda HC, Motta MF, Aguiar WM, Silva CC, Pinheiro PHM, Rocha VS. Relatório Técnico IPT/ASTEF/LPTS N ${ }^{\circ}$ 1: soldagem de juntas de aço inoxidável austenítico, duplex e superduplex. 2017.

34. ISO: International Organization for Standardization. ISO 68921: Metallic materials - Tensile testing - Part 1: method of test at room temperature. Geneva: ISO; 2010.

35. NACE: National Association of Corrosion Engineers. NACE SP0775: preparation, installation, analysis, and interpretation of corrosion coupons in oilfield operations. Houston: NACE; 2018.

36. Yang J, Wang Q, Wei Z, Guan K. Weld failure analysis of 2205 duplex stainless steel nozzle. Eng Fail Anal. 2014;2(2):69-75.

37. Dubé CA, Aaronson HI, Mehl RF. La formation de la ferrite proeutectoïde dans les aciers au carbone. Revue de metallurgie. 1958;55(3):201-210. https://doi.org/10.1051/metal/195855030201
38. Aaronson HI. The proeutectoid ferrite and the proeutectoid cementite reactions. In: Zackay VF, Aaronson HI, editors. Decomposition of austenite by diffussional process. New York: Interscience Publishers; 1960.

39. Yin J, Hillert M, Borgenstam A. Morphology of proeutectoid ferrite. Metall Mater Trans, A Phys Metall Mater Sci. 2017;48A:1425-43.

40. Londoño AJR. Estudo da precipitação de nitreto de cromo e fase sigma por simulação térmica da zona afetada pelo calor na soldagem multipasse de aços inoxidáveis duplex [dissertation]. São Paulo: Univresidade de São Paulo, 1997.

41. Rouby M, Blanchard P. Propriétés physiques et mécaniques des aciers et alliages inoxydables. In: Lacombe P, Baroux B, Béranger G, Colombier L, Hochmann, J, editors. Les aciers inoxydables. Les Ulis, France : Les Editions de Physique; 1990: pp. 565-610.

42. Anderson TD, Perricone MJ, DuPont JN, Marder AR. The influence of molybdenum on stainless steel weld microstructures. Weld J. 2007;86:281-92.

43. Ha HY, Jang MH, Lee TH, Moon J. Interpretation of the relation between ferrite fraction and pitting corrosion resistance of commercial 2205 duplex stainless steel. Corros Sci. 2014;89:154-62.

44. Ha HY, Lee TH, Lee CG, Yoon H. Understanding the relation between pitting corrosion resistance and phase fraction of S32101 duplex stainless steel. Corros Sci. 2019;149:226-35. http://dx.doi.org/10.1016/j.corsci.2019.01.001. 